\title{
Düzenleyici B Hücreleri ve Kanserdeki Rolü
}

\author{
Regulatory B Cells and Role In Cancer
}

\section{Berna Erdal ${ }^{1}$, Bahar Yilmaz ${ }^{2}$}

${ }^{1}$ Tekirdağ Namık Kemal Üniversitesi, Tip Fakültesi, Tibbi Mikrobiyoloji Anabilim Dalı, Tekirdăg, Türkiye

${ }^{2}$ Tekirdağ Namık Kemal Üniversitesi, Sağlık Bilimleri Enstitüsü, Tümör Biyolojisi ve İmmünolojisi Anabilim Dal, Tekirdă̆, Türkiye

Yazışma Adresi / Correspondence:

\section{Berna Erdal}

Tekirdağ Namık Kemal Üniversitesi, Tip Fakültesi, Tıbbi Mikrobiyoloji Anabilim Dalı, Tekirdağ, Türkiye

$$
\text { T: +90282 } 2505586 \quad \text { E-mail: berdal@nku.edu.tr }
$$

Geliş Tarihi / Received : 30.03.2020 Kabul Tarihi / Accepted : 21.05.2020

Orcid:

Berna Erdal https://orcid.org/0000-0003-3375-7926

Bahar Yllmaz https://orcid.org/0000-0001-8920-1754

( Sakarya Tip Dergisi / Sakarya Med J 2020, 10(2):326-333) DOI: 10.31832/smj.711179

$\ddot{\mathrm{O} z}$

Hümoral immün yanıt elemanı olan B hücreleri antikor üretiminden sorumlu hücrelerdir. Progenitör B hücreleri, kemik iliğinde olgunlaşırlar. B hücrelerinin yüzeyinde antijen reseptörleri, immünglobulin reseptörleri, adhezyon molekülleri ve Major Doku Uygunluk Kompleksi (MHC) molekülleri bulunur. Bu hücrelerin antijene bağlanma yeteneğinin gelișmesi sekonder lenfoid organlarda lenf foliküllerinin kendine özgü mikroçevresinde, $\mathrm{T}$ hücrelerine bağımlı olarak gerçekleșmektedir. Antijenik bir uyarım sonucunda aktive olan B hücreleri plazma hücrelerine ve sonrasında bellek B hücrelerine farklılaşıllar. Düzenleyici B (Breg) hücreleri, immünolojik toleransı destekleyen B hücrelerinin alt grubu olan immünsüpresif hücrelerdir. İnterlökin-10 (IL-10), IL-35 ve transforme edici büyüme faktörü beta (TGF- $\beta$ ) üreten Breg hücreleri, T hücrelerinin ve diğer pro-inflamatuar lenfositlerin ifadesini engelleyerek otoimmün patolojiyi baskılamaktadır. Son çalıșmalar, farklı inflamatuar ortamların farklı Breg hücre popülasyonlarını uyardığını göstermiştir. Hem insanlarda hem de hayvanlarda inflamasyon, transplantasyon, otoimmünite ve kanser modellerinde çeşitli Breg alt grupları tanımlanmıştır. Breg'lerin tümör oluşumunu baskıladığı ve terapötik amaçla kullanılabileceği yapılan farklı çalışmalar ile gösterilmiștir. Bu derlemede, Breg hücrelerinin işlevlerine ve kanserdeki rollerine genel bir bakıș sunulması amaçlanmaktadır.

Anahtar Düzenleyici B Hücre; İnterlökin-10; Kanser

Kelimeler

$B$ cells, the humoral immune response element, are the cells responsible for antibody production. Progenitor B cells, mature in bone marrow. The surface of $B$ cells contains antigen receptors, immunoglobulin receptors, adhesion molecules and Major Histocompatibility Complex $(\mathrm{MHC})$ molecules. The development of the ability of these cells to bind antigen occurs depending on $T$ cells in secondary lymphoid organsin the specific microenvironment of lymphfollicles. As a result of an antigenic stimulation, activated B cells differentiate into plasma cell and then memory $B$ cells. Regulatory B (Breg) cells, a subset of B cells, are immuno suppressive cells that support immunological tolerance. Interleukin (IL)-10, IL-35, and transforming growth factor beta (TGF- $\beta$ ) producing Breg cells inhibit auto immune pathology by preventing the expression of T cells and other pro-inflammatory lymphocytes. Recent studies have shown that different inflammatory environments induce different Breg cell populations. Various Breg subsets have been identified in inflammation, transplantation, autoimmunity and cancer models in both humans and animals. It has been shown in different studies that bregs suppress tumor formation and can be used for therapeutic purposes. In this review, it is aimed to provide an over view of functions and roles in cancer of Breg cells.

Keywords Regulatory B Cell; Interleukin-10; Cancer 


\section{GIIRIŞ}

B hücreleri olarak da bilinen B lenfositler, antikor salg1layan hücrelere (plazma hücreleri) farklılaşarak hümoral immün yanıtta görev alırlar. ${ }^{1} B$ hücrelerinin alt grubu olan düzenleyici B (Breg) hücreleri, İnterlökin (IL)-10, transforme edici büyüme faktörü beta (TGF- $\beta$ ) ve IL-35 gibi sitokinleri salgılayan immün modülatör etkiye sahip hücrelerdir. ${ }^{2}$ Breg hücrelerini diğer B hücre alt gruplarından ayıran spesifik bir transkripsiyon faktörü ya da yüzey belirteci bulunmamaktadır. ${ }^{3}$ Son yapılan çalışmalarda IL10 üretimi, Breg hücrelerinin tanımlayıcı bir özelliği olarak kabul edilmiştir. ${ }^{4}$ IL-10 üreten B hücrelerinin varlığı ilk kez, kronik bağırsak inflamasyonu oluşturulmuş rat modelinde keşfedilmiştir. ${ }^{5}$ Etkili immün yanıtın önemli ayırt edici özelliğinden biri olan inflamatuar yanıtın oluşturulması, patojenlerin eliminasyonu ve yara iyileşmesini (woundhealing) kontrol eden protein kaskadlarının başlatılması için kritik bir basamaktır. ${ }^{6}$ İnflamasyon, sağlıklı bir kişide kendini sınırlar. IL-10 gibi sitokinlerin ve anti-inflamatuar aracıların salgılanmasıyla kontrol edilen bu olaya "baskılama" veya "düzenleme” adı verilir. Sağlıksız ve kronik inflamasyonu olan kişilerde ise bağışıklık sistemi sürekli olarak uyarılır. Genellikle bu kişilerde dolaşımdaki ve inflamatuar bölgedeki bu baskılayıcı hücrelerin sayısında ve işlevinde azalma meydana gelebilmektedir. ${ }^{7}$ Esas olarak IL-10; IL-4, IL-5 ve IL-13 gibi sitokinleri salgılayan yardımcı T hücreleri (Th2) tarafından üretilir. Bununla birlikte Th1, Th17, sitotoksikCD8+ T hücreleri, mast hücreleri, dendritik hücreler (DC’ler), makrofajlar, doğal öldürücü (NK) hücreler, eozinofiller ve nötrofiller de IL-10 üretebilmektedirler. ${ }^{8-12}$ IL-10, TGF- $\beta$ ve IL-35 salg1layan Breg hücrelerini; tümör nekroz faktörü alfa (TNF- $\alpha$ ) üreten monositleri, IL-12 üreten dendritik hücreleri, Th17, Th1 ve CD8+ T hücreleri gibi pro-inflamatuar lenfositlerin farklılaşmasını baskılayabilir. Breg hücreleri ayrıca, Foxp3+ düzenleyici T (Treg) hücreleri ve düzenleyici Tr1 hücrelerinin farklılaşmasını indükleyebilir. Ek olarak Breg hücreleri, invariant doğal öldürücü T (iNKT) hücrelerinin oluşumunu desteklemektedir.
Farklı Breg alt grupları olan CD19+CD24yükCD38yük ve CD19+CD24yükCD27+hücrelerinin IL-10 ürettiği ve çeşitli hastalıklarda düzenleyici rolünün olduğu gösterilmiştir. Ancak insanlardaki fenotipleri tam olarak belirlenememiştir. ${ }^{13,14}$ Düzenleyici B hücreleri, IL-10 üretimi ile birçok hastalığın patogenezi ve ilerlemesinde önemli bir rol oynarlar. Özellikle IL-10 üreten Breg hücreleri CD8+ $\mathrm{T}$ hücrelerinden interferon-gama (IFN- $\gamma$ ) salgılanmasını ve antijen sunum mekanizmalarını baskılayarak kanser patogenezinde önemli rol oynamaktadır. Ayrıca Breg’lerin antitümoral özellikleri nedeniyle ilerleyen yıllarda kanserde yeni nesil tedavi yaklaşımları oluşturabileceği düşünülmektedir. ${ }^{2,4}$ Breg hücrelerinin antijene özgü ve spesifik olmayan immün düzenleyici mekanizmalar ile otoimmün hastalıklar ${ }^{15}$, kanser $^{4}$, alerjik hastalıklar ${ }^{9,16}$ ve transplantasyonda $^{10}$ rol oynadığ1 yapılan çalışmalarda gösterilmiştir. Ayrıca günümüzde in vitro olarak modifiye edilen Breg hücreleri terapötik olarak da kullanılabilmektedir. Bu derlemede Breg hücrelerinin gelişimsel kökeni, fenotipleri, alt grupları, işlevi ve kanserdeki rolleri açıklanacaktır.

\section{Düzenleyici B Hücreleri}

Gelişimi

B hücre gelişimi ve olgunlaşması antijenden bağımsız olarak primer lenfoid organ olan kemik iliğinde gerçekleşir. $\mathrm{Bu}$ hücreler kemik iliğinde karmaşık bir olgunlaşma sürecinde (pro-B, pre-B, immatür B ve matür B hücre) yüzey antijen reseptörlerini eksprese ederek fonksiyonel/fenotipik olarak olgunlaşırlar ve santral tolerans kazanırlar. ${ }^{17}$ Bu hücrelerin otoreaktif reseptör taşıyanları kemik iliğinde santral B hücre toleransı sağlayan negatif seleksiyon (apoptozis) veya reseptör spesifitelerinin değişimine bağlı mekanizmalar ile kontrol edilir. ${ }^{18}$

Anti-inflamatuar özelliklere sahip B hücrelerinin ilk keşfi 1970 'lere dayanmaktadır. ${ }^{19}$ Breg'ler, ilk olarak deneysel hayvan modelleri ile immün yetmezliği olan hastaların klinik değerlendirmesi ve hücre yüzey molekül karakterizasyonu yapılarak tanımlanmıştır. ${ }^{20,21}$ Çeşitli fare modellerinde Breg hücrelerinin kolit, artrit ve deneysel otoimmün 
ensefalomyelit (EAE)'in şiddetini azalttığ bulunmuştur. $^{22}$ Daha sonra, insanlarda yapılan çalışmalarda, Breg hücrelerinin immün yanıtı düzenlemede ve sürdürmede aktif rol oynadığı gösterilmiştir. $^{23}$

\section{Fenotipleri}

Breg'ler; IL-10, IL-35 ve TGF- $\beta$ üretimi yoluyla önemli immünmodülatör etkiler sergileyen $\mathrm{B}$ hücre alt grubudur. Breg'leri diğer B hücre alt gruplarından ayıran spesifik bir yüzey belirteci ve/veya transkripsiyon faktörü yoktur. ${ }^{3}$ Breg'lerin fonksiyonel olarak tanımlanması düzenleyici bir sitokin olan IL-10'un salgılanmasına göre yapılmakta$\operatorname{dir}^{24,25}$
Bugüne kadar farelerde ve insanlarda yapılan klinik çalışmalarda çeşitli Breg alt grupları tanımlanmıştır. Farelerde tanımlanan Breg alt grupları; Transizyonel 2 Marjinal Zon Prekürsör (T2-MZP) B hücreleri, MZ B hücreleri, IL-15 fusion trans gene (GIFT-15) B hücreleri, B10 hücreleri, plazmablastlar, plazma hücreleri, $\mathrm{T}$ hücresi Ig ve müsin alanı (Tim) -1+ B hücreleri, B-1a hücreleri, öldürücü B hücreleri ve PD-L1yük B hücreleridir. İnsanlarda tanımlanan Breg alt grupları ise plazmablastlar, olgunlaşmamış B hücreleri, B10 hücreleri, düzenleyici Granzim B (GrB)+ hücreleri ve düzenleyici B1 (Br1) hücrelerini içerir. ${ }^{26}$ Fareler ve insanlar üzerinde yapılan çalışmalarda tanımlanan farklı Breg hücre alt gruplarının fenotipleri ve fonksiyonları Tablo 1'de özetlenmiştir.

\begin{tabular}{|c|c|c|c|c|}
\hline Breg Alt Grupları & Fare Yüzey belirteci & İnsan Yüzey belirteci & Breg hücrelerinin Fonksiyonları & Ref. \\
\hline T2-MZP & $\begin{array}{l}\mathrm{CD} 19^{+} \mathrm{CD} 21 y^{\text {ük }} \\
\mathrm{CD} 23^{\text {yuk }} \mathrm{CD} 24^{\text {yük }}\end{array}$ & - & \multirow{2}{*}{$\begin{array}{l}\text { Dalakta bulunur, IL-10 üretir, Treg ve } \mathrm{CD} 4^{+} \text {ve } \\
\text { CD8 }{ }^{+} \mathrm{T} \text { hücrelerini baskllar. }\end{array}$} & 26 \\
\hline $\mathrm{MZ}$ & $\mathrm{CD} 19^{+} \mathrm{CD} 21^{\text {yük }} \mathrm{CD} 23^{-}$ & - & & 27 \\
\hline B10 & $\mathrm{CD}_{\mathrm{d}} \mathrm{d}^{\text {yuk }} \mathrm{CD}^{+}$ & $\begin{array}{l}\mathrm{CD} 19^{+} \mathrm{CD} 1 \mathrm{~d}^{\text {yuk }} \mathrm{CD} 5^{+} \mathrm{CD} 24^{\text {yik }}- \\
\mathrm{CD} 27^{+}\end{array}$ & $\begin{array}{c}\text { Dalakta (farelerde) ve kanda (insanlarda) bulunur, } \\
\text { IL-10 üretir, CD4 } 4^{+} \text {T hücrelerini, monositleri ve } \\
\text { DC'leri baskılar. } \\
\end{array}$ & 14 \\
\hline Bla & $\mathrm{CD}_{19}{ }^{+} \mathrm{CD}^{+}$ & & $\begin{array}{c}\text { Doğal antikorlar (IgM) üreterek patojenleri } \\
\text { nötralize eder }\end{array}$ & 28 \\
\hline $\begin{array}{l}\text { Öldürücü B } \\
\text { hücreleri }\end{array}$ & $\mathrm{FasL}^{+} \mathrm{CD}^{+} \mathrm{CD} 178^{+}$ & & $\begin{array}{l}\text { Dalakta bulunur, IL-10 ve IL-4 FasL aracilı } \\
\text { apoptozu uyarır. }\end{array}$ & 29 \\
\hline $\begin{array}{l}\text { Transizyonel } \\
\text { hücreler }\end{array}$ & & $\mathrm{CD} 19^{+} \mathrm{CD} 24^{y^{\text {yuk }} \mathrm{CD} 38^{\text {yük }}}$ & $\begin{array}{l}\text { IL-10 üretir, Treg'leri uyarır, Th1, Th17 ve CD8 }{ }^{+} \\
\text {T hücrelerini baskılar, iNKT hücre homeostazını } \\
\text { destekler. }\end{array}$ & 13 \\
\hline Plazma hücreleri & $\mathrm{CD}^{138^{+} \mathrm{MHC}-11 \text { düşB220 }}{ }^{+}$ & & $\begin{array}{l}\text { Kanda IL-10 üretimi ile CD } 4^{+} \text {T hücre çoğal- } \\
\text { masını baskılar. }\end{array}$ & 30 \\
\hline $\begin{array}{l}\text { LAG- } 3^{+} \text {plazma } \\
\text { hücreleri }\end{array}$ & LAG- $3^{+} \mathrm{CD} 138^{\text {yik }}$ & & $\begin{array}{l}\text { Dalakta bulunur, IL-10 ve IL-35 üreterek NK } \\
\text { hücrelerini, nötrofilleri ve CD4+ T hücrelerini } \\
\text { baskılar. }\end{array}$ & 31 \\
\hline Tim-1+ B hücreleri & Tim- $1^{+} \mathrm{CD} 19^{+}$ & & IL-10 üretir, Th1 hücrelerini baskılar. & 32 \\
\hline Plazmablastlar & $\mathrm{CD} 138^{+} \mathrm{CD} 44^{\text {yük }}$ & $\mathrm{CD} 19^{+} \mathrm{CD} 24^{\text {yik }} \mathrm{D} 27^{\text {int }}$ & IL-10 üretir ve $\mathrm{CD} 4^{+} \mathrm{T}$ hücrelerini baskılar. & 33 \\
\hline $\begin{array}{l}\text { GrB eksprese eden B } \\
\text { hücreleri }\end{array}$ & & $\begin{array}{l}\mathrm{CD} 19^{+} \mathrm{CD} 38^{+} \mathrm{CD} 1 \mathrm{~d}^{+} \mathrm{Ig}- \\
\mathrm{M}^{+} \mathrm{CD} 147^{+}\end{array}$ & $\begin{array}{l}\text { Lenf düğümleri (farelerde) ve kanda (insanlar- } \\
\text { da) bulunur, IL-10 üreterek DC'leri ve CD } 4^{+} \mathrm{T} \\
\text { hücrelerini baskılar. }\end{array}$ & 34 \\
\hline Br1 hücreleri & & 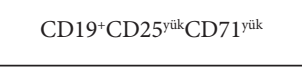 & $\begin{array}{l}\text { IL-21'in neden olduğu tümörlerde bulunur ve T } \\
\text { hücrelerini düzenler. }\end{array}$ & 35 \\
\hline GIFT-15 B hücreleri & $\begin{array}{c}\mathrm{B} 220^{+} \mathrm{CD} 21^{+} \mathrm{CD} 22^{+} \mathrm{CD}_{23}{ }^{+} \mathrm{CD} 24^{+} \mathrm{CD}- \\
\mathrm{ld}^{+} \mathrm{CD} 138^{+} \mathrm{IgD}^{+} \mathrm{IgM}^{+}\end{array}$ & & Kanda bulunur, IL-10 ve IgG üretir. & 36 \\
\hline PD-L1 yik & $\mathrm{PD}-1^{\text {yik }} \mathrm{CD} 19^{+} \mathrm{B} 220^{+}$ & & $\begin{array}{l}\text { Dalakta bulunur, IL-10 üreterek GM-CSF ve IL- } \\
\text { 15'in neden olduğu IFN tepkilerini baskilar. }\end{array}$ & 37 \\
\hline \multicolumn{5}{|c|}{$\begin{array}{l}\text { T2-MZP: Transizyonel } 2 \text { Marjinal Zon Prekürsör; MZ: Marjinal Zon; GIFT-15: IL-15 fusion trans gene; Tim-1: T hücresi Ig ve müsin alan1; PD-L1: programl- } \\
\text { anmış ölüm-ligand 1; GrB: Düzenleyici Granzim B hücreleri; Br1:düzenleyici B1; NK: Doğal Öldürücü Hücreler; Treg: T Regülatör Hücreleri; LAG-3: Lenfosit } \\
\text { Aktivasyon Geni 3; iNKT: İnvariant Doğal Öldürücü T Hücresi; DC: Dendritik Hücre; IFN: İnterferon; GM-CSF: Granülosit-Makrofaj Koloni Stimüle Edici } \\
\text { Faktör; Th1, Th17: Yardımcı T hücresi 1, 17; IgG, IgM: İmmün globülin G,M; Yük: Yüksek; Düş: Düşük. }\end{array}$} \\
\hline
\end{tabular}




\section{Farelerde Tanımlanan Breg Hücreleri}

Farelerde, fonksiyon ve yüzey belirteçleri birbirine benzeyen çok sayıda Breg hücre alt grubu tanımlanmıştır. Ancak tanımlanan bu hücre grupları arasında en çok araştırılanı IL-10 üretimi ile karakterize B10 hücreleri olmuştur. ${ }^{38}$ B10 hücrelerinden sonra en çok çalışılmış Breg hücre alt grubu ise Tim-1+ Breg hücreleridir. Böbrek yaralanmas1 molekülü (KIM-1) olarak da bilinen Tim-1, ilk olarak akut böbrek hasarı teşhisinde kullanılan bir belirteç olarak tanımlanmıştır. ${ }^{36}$ Sonraki çalışmalarda Th1 / Th2 dengesinde yer alan T hücresi ile ilişkili bir molekül olduğu keşfedilmiştir. ${ }^{39}$ Ding ve arkadaşlarının yapmış oldukları bir çalışmada ise Tim-1'in T hücreleri yerine B hücrelerinden eksprese edildiği ve IL-10 üreten B hücrelerinin \%70’inin Tim-1+ olduğu gösterilmiştir. ${ }^{32}$ Tim-1'in antogonistik bir Tim-1 antikoru ile bağlanması, Breg'lerin klonal gelişimini ve sitokin üretimini indükler. Bu bilgiler, B hücrelerinin düzenleyici ve inflamatuar özellikleri arasındaki dengede Tim-1'in önemli olduğunu göstermektedir. ${ }^{5}$

\section{İnsanlarda Tanımlanan Breg Hücreleri}

Breg'ler ile ilgili insanlarda yapılan araştırmalar, farelerdeki çalışmalara kıyasla sınırlı kalmıştır. Bugüne kadar insanlarda, periferik kandan çeşitli Breg fenotipleri tanımlanmıştır. Transizyonel B hücreleri (CD19+CD24yükCD38yük $)^{40}$, plazmablastlar $(\mathrm{CD} 19+\mathrm{CD} 27 \text { intCD } 38+)^{33}$ ve düzenleyici B1 (Br1) hücreleri (CD19+CD25+CD71+CD73p $)^{29}$ bu hücreler arasında sayılabilir. Ayrıca, CD19+CD24yükCD27+ fenotipi olan B10 hücrelerinin insanlarda bulunan tipi (Tim-1+Breg hücreleri) de bildirilmiştir. ${ }^{41}$ İnsanlarda yapılan çalışmalarda, Breg fenotipini tespit etmeye yarayan spesifik belirteçler bulunamamıştır. Breg hücreleri için karakteristik bir özellik olan IL-10 üretimi, olgunlaşmamış fenotip sergileyen Breg alt grupları için geçici bir özellik olabilir. İnsan Breg hücrelerine özgü bir transkripsiyon faktörü keşfedildiğinde bu hücrelere ait fenotipik özellikler aydınlığa kavuşacaktır.

\section{Breg Hücrelerinin Aktivasyonu ve Farklılaşması}

Breg'lerin aktive olabilmesi ve faklılaşması için çeşitli uyaranlara ihtiyacı olduğu bilinmektedir. Bunlardan biri olan Toll benzeri reseptörleri (TLR), infeksiyon ve otoimmüniteye karşı bağışıklık yanıtının aktivasyonu için önemli moleküllerdir. Yapılan in vitro ve in vivo çalışmalarla Breg hücrelerinin fonksiyonu üzerine TLR'lerin etkileri açıklanmaya çalışılmıştır. Örneğin MZ B hücrelerinin, TLR2 ve TLR4 ligandları aracılığı ile IL-10 üretebildiği gösterilmiştir. Ayrıca, bu yolla Breg hücre aktivasyonu için gerekli CD40-CD40L etkileşimi sonucunda Breg hücreleri sitokin üretimini arttırabilirler. Diğer taraftan, FOB hücreleri, TLR2 ve TLR4 uyarılması ile pro-inflamatuar sitokinler üretebilirler. $^{27}$ TLR' lerin Breg hücrelerinin baskılayıcı özellikleri üzerine etkisini anlamak için adaptör proteinler (MyD88 ve TLR2 veya TLR4) araştırılmıştır. Helicobacterfelis' in Breg hücrelerini TLR2 ve MyD88 yoluyla aktive ederek, infeksiyon durumunda Th1 hücre yanıtlarını baskıladığı gösterilmiştir.42 Ayrıca Breg’lerin gelişimi için $\mathrm{B}$ hücre reseptör (BCR) sinyali de gereklidir. BCR aktivitesinin yetersiz olduğu fare modellerinde, Breg hücrelerinin sayısının azaldığı rapor edilmiştir. ${ }^{39}$

İki bağımsız çalışmada Breg hücreleri tarafından Granzim B (GzmB) ekspresyonunun T hücre proliferasyonunu azalttığı belirtilmiştir. ${ }^{43,44}$ GzmB, sıklıkla T hücreleri ve NK hücrelerinin sitotoksik granüllerinde bulunan, apoptoz ve proliferasyonu baskılayan bir proteazdır. Bu etki mekanizması doğrultusunda FasL ekspresyonu yapan Breg hücrelerinin, CD4+ T hücre apoptozunu baskıladığı gösterilmiştir. ${ }^{45}$ Ayrıca hem farelerde hem de insanlarda yap1lan çalışmalarda Breg ve T hücreleri ya da CD80, CD86 ve MHC sınıf II'yi ifade eden DC'ler arasındaki ko-stimülatör etkileşimlerin önemli olduğu gösterilmiştir. İnsan Br1 hücrelerinde eksprese edilen programlanmıș ölüm-ligand 1 (PD-L1), T hücrelerinin aktivasyonunu baskılayan ve PD-1'e bağlanarak Treg'lerin uyarılmasını sağlayan inhibitör bir ko-stimülatör moleküldür. ${ }^{46}$ İnsan Breg fonksiyonunda rol oynadığ 1 düşünülen diğer ko-stimülatör moleküllerin CTLA-4, CD80 ve CD86 olduğu bilinmektedir. ${ }^{13}$ 


\section{Kanserde Breg hücrelerinin Rolï}

Breg hücrelerinin alerji, kanser, otoimmün hastalıklar, bağırsak inflamatuar ve bulaşıcı hastalıklar gibi farklı immünolojik hastalıklarda rolü olduğu düşünülmektedir. ${ }^{47}$ Tümör hücreleri üzerine immünmodülatör etkiye sahip Breg'lerin rolünün daha iyi anlaşılabilmesi için, kanser hastalarında Breg hücrelerinin düzeyleri araştırılmaktadır. Yapılan çalışmalarda Breg'lerin tümör oluşumu ve gelişimi ile yakından ilişkili olduğu düşünülmektedir. ${ }^{48}$ Halen Breg hücrelerinin çeşitli kanserlerdeki rolleri açıklanmaya çalışılmaktadır.

\section{Meme Kanseri}

Meme kanseri, dünyada kadınlar arasında en sık görülen maling tümörlerden biridir. Yapılan çalışmalar sonucunda invaziv meme karsinomlu hastalarda, IL-10 üretimi yoluyla Breg hücrelerinin sayısının arttığı gösterilmiştir. ${ }^{49}$ Mehdipour ve arkadaşları, TGF- $\beta$ aracılı Treg uyarılmasının bloke edilmesinin yanında Breg hücrelerinin baskılanması ile IL-10'un baskılanması meme kanseri metastazının önlenmesinde potansiyel bir terapötik yaklaşım olabileceğini öne sürmüşleridir. ${ }^{50}$ Başka bir çalışmada kanser anjiyogenez inhibitörü olan ve p53, Rb ve hücre döngüsündeki kinazları hedef alarak hücre apoptozunu kontrol ettiği bilinen resveratrolün (RSV) meme kanseri üzerine çeşitli dozları araştırılmıştır. Bu çalışma sonunda RSV'nin, Breg'leri etkisiz hale getirerek metastazı baskıladığı gösterilmiştir. ${ }^{51}$

\section{Özofagus kanseri}

Özofagus kanseri (EC), sindirim sistemi ile ilişkili kanserler arasında kötü prognoza sahip bir kanser grubudur. ${ }^{52}$ 2014 yılında Shi ve arkadaşları tarafından yapılan bir çalışmada; EC hastalarında CD5+CD19+B hücresinden salgilanan IL-10'un, TGF- $\beta$ ve Foxp3+ fonksiyonlarını arttırdığı bildirilmiştir. Hastalarda sağlıklı kontrollere kıyasla daha yüksek oranda CD5+CD19+Foxp3+Breg hücreleri tespit edilmiştir. Bu bulgular, Breg hücrelerinin EC’nin gelişiminde ve ilerlemesinde immün düzenleyici bir rolünün olduğunu göstermektedir. ${ }^{53}$

\section{Hepatoselüler Karsinom}

Hepatoselüler karsinom (HCC), birçok gen ve proteinin ekspresyonundaki değişiklikler ile karakterize olan, dünya çapında en yaygın görülen kanserlerden biridir. ${ }^{54}$ Shao ve arkadaşları yapmış oldukları bir çalışmada, sağlıklı kişilere kıyasla HCC hastalarında Breg hücrelerinin yüzdesinde anlamlı bir artış saptamışlardır. Ayrıca, Breg'ler ve HCC hücreleri birlikte kültüre edildiğinde, CD40/CD40L etkileşiminin baskılanmasının; TGF- $\beta 1$ ve IL-10 salgılanmasında azalmaya, TNF- $\alpha$ salgılanmasında ise artışa neden olduğunu göstermişlerdir. Başka bir çalışmada, HCC gelişimi ile baskın IL-10 artışı ve TNF- $\alpha$ azalması arasında bir ilişkinin olduğu tespit edilmiştir. Bu nedenle, anti-CD40 antikoru aracılığ 1 ile Breg hücrelerinin tükenmesine neden olan veya tümör hücresi ile Breg hücre etkileşimini bozan yeni stratejilerin HCC için potansiyel terapötik bir yaklaşım olabileceği düşünülmektedir. ${ }^{55}$

\section{Baș-Boyun Kanserleri}

Baş ve boyun yassı epitel hücreli kanserleri(HNSCC) en agresif kanser türüdür. Diğer kanserler ile karşılaştırıldığında 5 yıllık sağ kalım oranı \%50'den azdır. Fakat HNSCC immünoterapötik yaklaşımlara yanıt vermesi açısından immünojenik bir tümör olarak kabul edilmektedir. ${ }^{56}$ Tümör mikroçevresinde Breg'lerde dahil olmak üzere birçok immünsüpresyon mekanizma tanımlanmıştır. ${ }^{57}$ Sandra ve arkadaşlarının 2020 yılında HNSCC'de adenosin (ADO) üreten Breg hücreleri ile yaptıkları bir çalışmada, Breg’lerin $\mathrm{T}$ hücrelerinin fonksiyonunu baskıladığı gösterilmiştir. ${ }^{58}$ Araştırmacılar farelerde ve insanlarda tümör mikroçevresi içinde ADO üreten Breg popülasyonunun varlığını gösteren bu çalışma sonuçlarının, yapılacak başka in vivo çalışmalar için model oluşturacağını ve B hücrelerindeki ADO yolu modülasyonunun, kanser hastalarında uygulanabilecek terapötik bir yaklaşım olabileceğini ileri sürmüşlerdir.

\section{Servikal Kanserler}

Servikal kanser (Rahim ağzı kanseri), morbidite ve mortalite açısından kadın genital sistem tümörlerinde ikinci 
sırada yer alan bir kanser türüdür. ${ }^{59}$ Son zamanlarda, artan vaka sayısı ile bu kansere spesifik immünoterapilere olan ilgi artmaktadır. Chen ve arkadaşlarının 2019 yılında serviks kanseri gelişiminde Breg hücrelerinin rolünü araştırdıkları çalışmalarında, hastaların klinik semptomlarını ve Breg hücre seviyelerini analiz ettiklerinde serviks kanserinde Breg hücrelerinin önemli ölçüde arttığını ve bu hücrelerin hastalığın ilerlemesi ile yakından ilişkili olduğunu göstermişlerdir. ${ }^{60}$ Son yıllarda serviks kanseri hastalarında Breg hücrelerinin azaltılmasının veya işlevinin bloke edilmesinin immünoterapide hedef olarak kullanılabileceği düşünülmektedir.

\section{Pankreas Kanseri}

Pankreas kanseri, gastrointestinal sistem ile ilişkili kanserlerin başında gelmektedir. ${ }^{61}$ IL-18, inflamasyon ve immün yanıtta kritik rol oynayan, T ve NK hücrelerinde IFN- $\gamma$ üretimini uyaran, anti-tümoral etkileri bulunan bir sitokindir. IL-18 tarafından indüklenen Breg hücrelerinde PD-1/PD-L1 yoluyla immün tolerans oluşumunun araştırıldığı bir çalışmada; IL-18'in Breg'lerin immünsüpresyonunu arttırdığı bildirilmiştir. ${ }^{48} \mathrm{Bu}$ çalışma sonucunda IL-18 ve PD-1/PD-L1'in pankreas kanserinde terapötik bir hedef olarak kullanılabileceği gösterilmiştir.

\section{SONUÇ}

Son yıllarda Breg hücreleri ile ilgili yapılan çalışmalardan elde edilen veriler, bu hücrelerin immün sistemde önemli rol oynadığını ve gelecekte Breg hücre alt gruplarının çeşitli hastalıkların tedavisinde terapötik hedef olabileceğini göstermektedir. Bu amaçla Breg hücrelerinin proliferasyonun önlenmesi ve/veya işlevlerinin bloke edilmesi ile meme, pankreas, servikal kanserler gibi çeşitli malignitelerin tedavisinde önemli aşamalar kaydedilebileceği düşünülmektedir. Bununla birlikte, tüm Breg hücrelerinin inhibisyonu, inflamasyonu baskılayan Breg hücrelerinin ortadan kaldırılması nedeniyle dezavantajlıdır. Bu nedenle, hastalığın türüne bağlı olarak Breg hücre alt gruplarının seçici olarak baskılanması gerekmektedir. Bu bağlamda, özellikle Breg hücrelerini hedefleyen tedavileri geliştirmek için bu hücrelerin farklılaşmasını ve proliferasyonunu uyaran spesifik moleküllerin iyi tanımlanması gerekmektedir. Breg hücrelerinin özelliklerini, aktivasyon mekanizmalarını ve işlevlerini kapsamlı bir şekilde anlamak için daha fazla sayıda yapılacak in vitro ve in vivo çalışmalara ihtiyaç vardir. 


\section{Kaynaklar}

1. You Chao D, Jixin Z, Jun-Fa X. Regulatory B Cells İn İnfectious Disease. Molecular Medtcine Reports 2017;16:3-10.

2. Rowa YA. Regulatory B cells: Development, phenotypes, functions, and role in transplantation. Immunological Reviews 2019;00:1-16.

3. Rosser EC, Mauri C. Regulatory B cells: origin, phenotype and function. Immunity 2015;42(4):607-612.

4. Mauri C, Bosma A. Immune regulatory function of B cells. Annu Rev Immunol. 2012;30:221-241.

5. Fitzgerald DC, et. Al. Suppression of autoimmune inflammation of the central nervous system by interleukin 10 secreted by interleukin 27-stimulated T cells. Nat. Immunol. 2007;8(12):1372-1379

6. Medzhitov R. Origin and physiological roles of inflammation. Nature 2008;454:428-435.

7. Nathan C, Ding A. Non resolving inflammation. Cell 2010;140:871-882.

8. Maynard CL, Weaver CT. Diversity in the contribution of interleukin-10 to T-cell-mediated immune regulation. Immunol. Rev. 2008;226(1):219-233.

9. Saraiva M, Christensen JR, Veldhoen M, Murphy TL, Murphy KM, O'Garra A. Interleukin-10 production by Th1 cells requires interleukin-12-induced STAT4 transcription factor and ERK MAP kinase activation by high antigen dose. Immunity 2009;31(2):209-219.

10. Gilliet M, Liu YJ. Generation of human CD8 T regulatory cells by CD40 ligand activated plasma cytoid dendritic cells. J. Exp. Med. 2002;195(6):695-704.

11. Grimbaldeston MA, Nakae S, Kalesnikoff J, Tsai M, Galli SJ. Mastcell-derivedi nterleukin 10 limits skin pathology in contact dermatitis and chronic irradiation with ultraviolet $B$. Nat. Immunol.2007;8(10):1095.

12. Moore KW, de Waal Malefyt R, Coffman RL, O'Garra A. Interleukin-10 and the interleukin-10 receptor. Аnпu. Rev. Immunol.2001;19(1):683-765.

13. Blair PA, Noreña Y, Flores-Borja F, Rawlings D.J, Isenberg D.A, Ehrenstein M.R, et al. $C D 19+C D 24 h i C D 38 h i$ B cells exhibit regulatory capacity in healthy individuals but are functionally impaired in systemic lupus erythematosus patients. Immunity 2010;32(1):129140.

14. Iwata Y, Matsushita T, Horikawa M, DiLillo DJ, Yanaba K, Venturi G.M, et al. Characterization of a rare $I L-10$ competent $B$-cell subset in humans that parallels Mouse regulatory B10 cells. Blood 2011;117(2):530-541.

15. McGeachy MJ, Bak-Jensen KS, Chen Y, Tato CM, Blumenschein W, McClanahan T, et al. TGF- $\beta$ and IL- 6 drive the production of $I L-17$ and $I L-10$ by $T$ cells andrestrain $T H-17$ cell-mediated pathology. Nat. Immunol.2007;8(12):1390-1397.

16. Stumhofer JS, Silver JS, Laurence A, Porrett PM, Harris TH, Turka LA, et al. Interleukins 27 and 6 induce STAT3 mediated T cell production of interleukin 10. Nat. Immunol.2007;8(12):1363-1371.

17. Delves PJ, Roitt IM. The immune system. First of two parts. N Engl J Med. 2000;6,343(1):3749.

18. Öztürk E. B hücre aktivasyonu ve antikor üretimi. Türkdem2013;47:Özel Sayı 1: 24-7.

19. Mizoguchi A, Mizoguchi E, Takedatsu H, Blumberg RS, Bhan AK. Chronic intestinal inflammatory condition generates IL-10-producing Immunity Perspective regulatory B cell subset characterized by CD1d upregulation. Immunity2002;16: 219-230.

20. Lai G, Nakayama Y, Burrell BE, Ding Y, Bromberg JS. Non-humoral functions of B cells is required for tolerance. Am J Transplant2011;11: 105.

21. İthan F, Taş SK. Organ Nakillerinde Regülatör B Hücrelerin Rolü. Turkiye Klinikleri J Immun Allergy-Special Topics 2013;6(2):29-35.

22. Adams AB, Newell KA. B cells in clinical transplantation tolerance. Semin Immunol. 2012;24 (2):92-5.

23. Duddy ME, Alter A, Bar-Or A. Distinct profiles of human B cell effect or cytokines: a role in immune regulation. J Immunol. 2004;172(6):3422-3427.

24. Wortel CM, Heidt S. Regulatory B cells: Phenotype, function and role in transplantation. Transplant Immunology 2017; 41:1-9.

25. Valizadeh A, Sanaeib R, Rezaeia N, Azizid G, Fekrvanda S, Aghamohammadia A, et al. Potential role of regulatory $B$ cells in immunological diseases.Immunology Letters 2019;215:48-59.

26. Carter NA, Vasconcellos R, Rosser EC, Tulone C, Muñoz-Suano A, Kamanaka M, et al. Mice lacking endogenous IL-10-producing regulatory $B$ cells develop exacerbated disease and present with an increased frequency of Th1/Th17 but a decrease in regulatory $T$ cells. J. Immunol. 2011;186(10):5569-5579.

27. Gray M, Miles K, Salter D, Gray D, Savill J. Apoptotic cells protect mice from autoimmune inflammation by the induction of regulatory B cells, Proc. Natl. Acad. Sci. U. S. A. 2007;104 (35): 14080-14085.

28. Zhang X, Deriaud E, Jiao X, Braun D, Leclerc C, Lo-Man R. Type I interferons protect neo nates from acute inflammation through interleukin 10-producing B cells. J. Exp. Med. 2007;204(5):1107-1118.

29. Lundy SK, Fox D.A. Reduced Fas ligand-expressing splenic CD5+ B lymphocytes in severe collagen-induced arthritis. Arthritis Res. Ther. 2009;11(4):R128.

30. Khoder A, Sarvaria A, Alsuliman A, Chew C, Sekine T, Cooper N, et al. Regulatory B cells are enriched with inthe IgM memory and transitional subsets in healthy donors but are deficient in chronic GVH. Blood. 2014;124(13): 2034-2045.

31. Lino AC, Lampropoulou V, Welle A, Joedicke J, Pohar J, Simon Q, et al. LAG-3 inhibitory receptor expression identifies immuno suppressive natural regulatory plasma cells. Immunity 2018;49(1):120-133

32. Ding Q, Yeung M, Camirand G, Zeng Q, Akiba H, Yagita H, et al. Regulatory B cells are identified by expression of TIM-1 and can be induce dthrough TIM-1 ligation topromote tol-eranceinmice. J. Clin. Invest. 2011;121(9):3645-3656.

33. Matsumoto M, Baba A, Yokota T, Nishikawa H, Ohkawa Y, Kayama H, et al. Interleukin-10-producing plasmablasts exert regulatoryfunction in autoimmune inflammation. Immunity 2014;41(6):1040-1051.

34. Lindner S, Dahlke K, Sontheimer K, Hagn M, Kaltenmeier C, Barth T.F, et al. Interleukin 21-induced granzyme B-expressing B cells infiltrate tumors and regulate $T$ cells. Cancer Res. 2013;73(8):2468-2479.

35. Van de Veen W, Stanic B, Yaman G, Wawrzyniak M, Söllner S, Akdis D.G, et al. IgG4 production is confined tohuman IL10-producing regulatory B cells that suppress antigen-specific immune responses. J. Allergy Clin. Immunol. 2013;131(4):1204-1212.

36. Rafei M, Hsieh J, Zehntner S, Li M, Forner K, Birman E, et al. A granulocyte-macrophage colony-stimulating factor and interleukin-15 fusokine induces a regulatory $B$ cell population with immune suppressive properties. Nat. Med. 2009;15(9):1038-1045.

37. Khan AR, Hams E, Floudas A, Sparwasser T, Weaver CT, Fallon PG. PD-L1hi B cells are critical regulators of humoral immunity, Nat. Commun. 2015;6: 5997.

38. Watanabe R, Ishiura N, Nakashima H, Kuwano Y, Okochi H, Tamaki K. Regulatory B cells (B10 cells) have a suppressive role in murine lupus: CD19 and B10 cell deficiency exacer bates systemic autoimmunity. J. Immunol. 2010;184(9):4801-4809.

39. Kalampokis I, Yoshizaki A, Tedder TF. IL-10-producing regulatory B cells (B10 cells) in autoimmune disease. Arthritis Res. Ther. 2013;15(1): S1.

40. Xiao S, Brooks CR, Sobel RA, Kuchroo VK. Tim-1 is essential for inductionand maintenance of IL-10 in regulatory B cells and their regulation of tissue inflammation. J. Immunol. 2015;194(4):1602-1608.

41. Gasperi C, Melms A, Schoser B, Zhang Y, Meltoranta J, Risson V, et al. Anti-agrin auto antibodies in myas then iagravis. Neurology 2014;82(22):1976-1983.

42. Sayi A, Kohler E, Toller I.M, Flavell R.A, Muller W, Roers A, et al. TLR-2-activated B cells suppress Helicobacter-induced pre neoplastic gastric immunopathology by inducing $T$ regulatory-1 cells. J Immunol. 2011;186:878-890.

43. Chesneau M, Michel L, Dugast E, Chenouard A, Baron D, Pallier A. Tolerant kidney transplant patients produce B cells with regulatory properties. J. Am. Soc. Nephrol. 2015;26(10):2588-2598.

44. Zeng Q, Ng Y.H, Singh T, Jiang K, Sheriff KA, Ippolito R. B cells mediate chronic allo graft rejectionin dependently of antibody production. J. Clin. Invest. 2014;124(3):1052-1056.

45. Maseda D, Smith SH, DiLillo DJ, Bryant JM, Candando KM, Weaver CT. Regulatory B10 cells differentiate into antibody-secreting cells after transient IL-10 production in vivo. J. Immunol. 2012;188(3):1036-1048.

46. Deng S, Moore DJ, Huang X, Lian MM, Mohiuddin M, Velededeoglu E. Cuttingedge: trans plant tolerance induced by anti-CD45RB requires B lymphocytes. J. Immunol. 2007;178 (10):6028-6032.

47. Tarique M, Naz H, Kurra SV, Naqvi RA, Saini C, Rai R, et al. IL-10-producing regulatory $B$ cells transformed CD4+CD25- into Tregs and enhanced regulatory $T$ cells function in human leprosy. Front. Immunol. 2018;9: ID1636.

48. Zhao $Y$, Shen $M$, Feng $Y, H e R, X u X, X i e Y$, et al. Regulatory $B$ cells induced by pancreatic cancer cell-derived interleukin-18 promote immune tolerance via the PD-1/PD-L1 pathway. Oncotarget 2018;9(19):14803-14814.

49. Lee-Chang C, Bodogai M, Martin-Montalvo A, Wejksza K, Sanghvi M, Moaddel De Cabo $R$, et al. Inhibition of breast cancer metastasis by resveratrol-mediated inactivation of tumor-evoked regulatory B cells, J. Immunol. 2013;191(8):4141-4151.

50. Mehdipour F, Razmkhah M, Hosseini A, Bagheri M, Safaei A, Talei AR, et al. B regulatory phenotype in non-metastatic lymphnodes of node-positive breast cancer patients. Scand. J. Immunol. 2016;83(3):195-202.

51. Lee-Chang C, Bodogai M, Martin-Montalvo A, Wejksza K, Sanghvi M, Moaddel De Cabo $R$, et al. Inhibition of breast cancer metastasis by resveratrol-mediated inactivation of tu- 
Sakarya Tip Dergisi 2020;10(2):326-333

mor-evoked regulatory B cells, J. Immunol. 2013;191(8):4141-4151.

52. Ferlay J, Shin HR, Bray F, Forman D, Mathers C, Parkin DM. Estimates of worldwide burden of cancer in 2008: GLOBOCAN 2008, Int. J. Cancer 2010;127(12):2893-2917.

53. Shi J, Li S, Zhou Y, Wang L, Wen J, Wang Y, et al. Perio perative changes in peripheral regulatory B cells of patients with esophageal cancer. Mol. Med. Rep. 2014;10(3):1525-1530.

54. Aravalli RN, Cressman EN, Steer CJ. Cellular and molecular mechanisms of hepato cellular carcinoma: an update. Arch. Toxicol. 2013;87(2):227-247.

55. Shao Y, Lo CM, Ling C, Liu XB, Ng KTP, Chu ACY, et al. Regulatory B cells accelerate hepato cellular carcinoma progressionvia CD40/CD154 signaling pathway, Cancer Lett. 2014;355(2):264-272.

56. Meucci S, Keilholz U, Tinhofer I, Ebner OA. Mutation allo adand mutational patterns in relation to age in head and neck cancer. Oncotarget 2016;7: 69188-69199.
57. Ferris RL, Blumenschein GJ, Fayette J. Nivolumab for recurrent squamous-cell carcinoma of the head and neck. N Engl J Med 2016;375:1856-1867.

58. Jeske SS, Brand M, Ziebart A. Adenosine-producing regulatory B cells in head and neck cancer. Cancer Immunol Immuno ther. 2020

59. Wardak S. Human papillomavirus (HPV) and cervical cancer. Medycyna Doświadczalna i Mikrobiologia 2016;68(1):73-84.

60. Chen Z, Zhu Y, Du R, Pang N, Zhang F, Dong D, et al. Regulatory B Cells in the Progression of Cervical Cancer. Hindawi Mediators of Inflammation2019;Article ID 6519427.

61. Kim R, Emi M, Tanabe K. Cancer immuno editing from immune surveillance to immune escape. Immunology 2007;121:1-14 